\title{
Comparison of seeded and native pastures grazed from mid-May through September
}

\author{
L. HOFMANN, R.E. RIES, J.F. KARN, AND A.B. FRANK
}

Authors are research agronomist, range scientist, research animal scientist, and plant physiologist, USDA-ARS, P.O. Box 459, Mandan, N.D.

\begin{abstract}
Cool-season introduced grass species are not recommended for season-long grazing in the northern Great Plains. They mature earlier than native species, which leads to an earlier loss in forage quality and palatability. A study conducted at Mandan, N.D., compared liveweight gains of yearling steers grazing crested wheatgrass [Agropyron desertorum (Fisch. ex Link) Schult.], smooth bromegrass (Bromus inermis Leyss.), and western wheatgrass [(Pascopyrum smithii (Rydb.) Löve] and level native prairie (Class II and III land) and hilly native prairie pastures (Class IV and VI land), seasonlong. A set stocking rate of $1.5 \mathrm{AUM} \mathrm{ha}^{-1}$ was used from mid-May through late September in 1988, 1989, and 1990. Caged standing crop was higher from the seeded pastures than from the native pastures but liveweight steer gain was highest from the level native. Three-year average gains were $124,114,108$, 106 , and $105 \mathrm{~kg}$ per steer for level native, smooth bromegrass, western wheatgrass, hilly native, and crested wheatgrass pastures, respectively. The seeded cool-season grass pastures, grazed seasonlong at a rate $25 \%$ higher than that recommended by the SCS for native range, produced acceptable liveweight steer gains without additional inputs. Season-long grazing may provide an alternative use for marginal cropland and other highly erodible land that has been reseeded to cool-season species.
\end{abstract}

Key Words: crested wheatgrass, smooth bromegrass, western wheatgrass, level native, hilly native, liveweight gain, standing crop, season-long grazing

Introduced cool-season grass species, used as cool-season pasture, have increased overall livestock production in the northern Great Plains. These grasses are most palatable during the early part of the grazing season and have been recommended for spring and early summer grazing (Sarvis 1941, Rogler et al. 1962, Frischknecht and Harris 1968, Rogler and Lorenz 1969). However, Williams and Post (1945) reported that pastures seeded to fairway crested wheatgrass [A. cristatum (L.) Gaertner] furnished a longer grazing season than smooth bromegrass (Bromus inermis Leyss.) pasture or native range. Average daily gain per animal (ADG) was similar on all pastures. Crested wheatgrass and smooth bromegrass, stocked at 2.5 and 1.7 times heavier than native pastures, respectively, produced 2.1 and 1.4 times the average total animal gain per acre of the native pasture. Livestock on the crested wheatgrass pastures averaged $0.9 \mathrm{~kg} \mathrm{ADG}$ or more for 75 out of 117 days of grazing over 9 years. Williams and Post concluded, "On the basis of this analysis it seems logical that crested wheatgrass should be utilized early in the season and for an average of about 75 days for maximum results. During this period the pasture should be stocked heavily enough to prevent the crested wheatgrass from

\footnotetext{
This article is a contribution from USDA-ARS, Mandan, N.D.

Manuscript accepted 6 Oct. 1992.
}

becoming coarse and mature."

Hofmann and Ries (1989) compared yearling steers grazing cool-season reclaimed mineland pastures with steers grazing native pasture, from late May through September. The reclaimed pastures were dominated by a mixture of smooth bromegrass and alfalfa (Medicago sativa $\mathbf{L}$.). Liveweight gains of steers for a 126day grazing season were similar from all pastures. Laycock and Layden (1985) also obtained excellent summer-long cattle gains from reclaimed mined land dominated by alfalfa, intermediate wheatgrass [ Thinopyrum intermedium (Host) Barkworth \& D.R. Dewey subsp. intermedium, and smooth bromegrass.

These latter findings suggested that early, short-season use may not be the only approach to grazing cool-season introduced grasses in the northern Great Plains. Our objectives were to evaluate the use of seeded stands of standard crested wheatgrass [Agropyron desertorum (Fisch. ex Link) Schult.], smooth bromegrass, and western wheatgrass [Pascopyrum smithii (Rydb.) Löve], native mixed prairie on Class II and III land (level native) and mixed prairie on Class IV and VI land (hilly native) as season-long pastures. Forage production and liveweight yearling steer gain were compared.

\section{Materials and Methods}

The research site was located at Mandan, N.D. Seeded and level native pastures were located on 98 ha of predominately Wilton silt loam, 2 to $3 \%$ slope (fine-silty, mixed Pachic Haploborolls) and Temvik silt loam, 3 to $6 \%$ slope (fine-silty, mixed Typic Haploborolls). The hilly native pastures were located on 24 ha of a WernerSen-Chama Complex (loam, silt loam, and silty clay loam Entic and Typic Haploborolls) with 9 to $25 \%$ slopes. None of the study areas were fertilized after 1982.

Perennial grass sod, which had been used for grazing experiments and reserve pasture since 1976, was plowed in fall 1983 and fallowed in 1984. Spring wheat (Triticum aestivum $\mathrm{L}$.) was planted in May 1985. In August, the grain was harvested using a combine equipped with a straw spreader. After harvest, the 3 grass species were randomized into each of 4 blocks and directly seeded into the wheat stubble with a no-till grain drill. Seeding rates were 9.0, 5.6, and $6.7 \mathrm{~kg}$ pure live seed $\mathrm{ha}^{-1}$ of 'Nordan' crested wheatgrass, 'Lincoln' smooth bromegrass, and 'Rodan' western wheatgrass, respectively.

The level native prairie area and the hilly prairie area were each divided into 4 pastures. Each native pasture was considered a sample because site restrictions made it impossible to randomize these areas among the seeded areas. These native prairie areas had been used as reserve pastures for over 20 years and were lightly grazed through 1984 and not grazed during 1985 or 1986.

The crested wheatgrass, smooth bromegrass, and native pastures were grazed for 133 days from late May through early 
October in 1987. Western wheatgrass pastures were not grazed in 1987 because they establish slowly and usually require 2 years to produce grazable stands.

Three yearling Hereford steers (Bos taurus) were used to graze

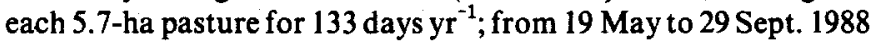
and 1989, and from 27 May to 4 Oct. 1990. Set stocking rates were 1.5 AUM ha ${ }^{-1}$, which was slightly heavier than the $1973 \mathrm{SCS}$ recommended rate of $1.2 \mathrm{AUM} \mathrm{ha}^{-1}$. Steers were weighed, following an overnight shrink off water and feed, at 21-day intervals except that the final interval had 28 days. Starting weights, which averaged $320 \mathrm{~kg}$, and ending weights were obtained by averaging weights from 3 consecutive days. Water and trace mineralized salt were offered free choice throughout the grazing season.

In July 1990, fifteen 10-point frame basal ground cover readings were taken randomly across each pasture and averaged over the 4 pastures of each type to determine plant composition. Planted species dominated the seeded pastures (Table 1). Soil and topography differences between the level and hilly native pastures were

Table 1. Species composition of seeded and native pastures in July 1990.

\begin{tabular}{|c|c|c|c|c|c|}
\hline Species & $\begin{array}{l}\text { Level } \\
\text { native }\end{array}$ & $\begin{array}{l}\text { Hilly } \\
\text { native }\end{array}$ & $\begin{array}{c}\text { Smooth } \\
\text { brome- } \\
\text { grass }\end{array}$ & $\begin{array}{c}\text { Western } \\
\text { wheat- } \\
\text { grass }\end{array}$ & $\begin{array}{c}\text { Crested } \\
\text { wheat- } \\
\text { grass }\end{array}$ \\
\hline $\begin{array}{l}\text { Blue grama } \\
\quad \text { [Bouteloua gracilis (H.B.K.) }\end{array}$ & $\begin{array}{c}34 \\
\text { Griffits] }\end{array}$ & 23 & (\% of live) & $+\cdots$ & -- \\
\hline $\begin{array}{l}\text { Sedges } \\
\quad \text { (Carex spp.) }\end{array}$ & 43 & 39 & - & - & - \\
\hline $\begin{array}{l}\text { Green needlegrass } \\
\quad \text { (Stipa viridula Trin.) }\end{array}$ & 3 & 8 & - & - & - \\
\hline $\begin{array}{l}\text { Needleandthread } \\
\quad(S . \text { comata } \text { Trin.) }\end{array}$ & 6 & 4 & - & - & - \\
\hline $\begin{array}{l}\text { Threeawn } \\
\text { (Aristida spp.) }\end{array}$ & 1 & - & - & - & - \\
\hline $\begin{array}{l}\text { Kentucky bluegrass } \\
\text { ( Poa pratensis L.) }\end{array}$ & 6 & 5 & - & 7 & - \\
\hline Western wheatgrass & 4 & - & - & 81 & 2 \\
\hline Crested wheatgrass & - & - & - & 9 & 94 \\
\hline $\begin{array}{l}\text { Smooth bromegrass } \\
\text { Other species }\end{array}$ & $\overline{3}$ & $\overline{12}$ & $\begin{array}{r}97 \\
3\end{array}$ & $\overline{3}$ & $\begin{array}{l}2 \\
2\end{array}$ \\
\hline Forbs & - & 9 & - & - & - \\
\hline
\end{tabular}

accompanied by differences in species composition. Patches of western snowberry (Symphoricarpos occidentalis Hook) and buffaloberry [Shepherdia argentea (Pursh) Nutt.] were scattered throughout the hilly pastures.

Standing crop was estimated by cutting three 0.38 by $3.0-\mathrm{m}$ strips at $5.0 \mathrm{~cm}$ height with a sickle bar mower on 20 Sept. 1988, 26 Sept. 1989, and 2Oct. 1990. Caged standing crop was sampled under three 0.9 by $4.3-\mathrm{m}$ protective cages within each pasture. These cages were randomly placed at a new location each spring. Ungrazed residue was measured from the standing crop remaining on the grazed portion of each pasture at the end of the scason. Standing crop disappearance was estimated by subtracting the caged standing crop from the ungrazed residue.

Percent utilization $=\frac{\text { caged standing crop }- \text { ungrazed residue }}{\text { caged standing crop }} \times 100$.

All crop dry matter is reported on an oven-dry $\left(60^{\circ} \mathrm{C}\right)$ basis.

Climatic data were obtained from a weather station location about $5 \mathrm{~km}$ north of the study area. Heat and/or water stress were high during much of the 3 years of study. Total precipitation from 1 Sept. 1987 to 31 July 1988 was $212 \mathrm{~mm}$ less than the long-term (1951-1980) average of $354 \mathrm{~mm}$ for the same period. The low precipitation trend continued from September 1988 until mid-May 1990 with $430 \mathrm{~mm}$ precipitation received compared to the longterm average of $679 \mathrm{~mm}$.

Since the native pastures were not blocked among all treatments, data were analyzed as a completely random design by analysis of variance. Animal liveweight gain and standing crop production means with significant $\mathrm{F}$ values $(P<0.05)$ were compared using the Waller-Duncan test. Yearly accumulated liveweight gains for periods were compared using LSD [conditional on a significant $F$ test $(P<0.05)]$.

\section{Results and Discussion}

Over the 3 years, western wheatgrass produced the highest average $(P<0.05)$ caged standing crop dry matter followed by crested wheatgrass, smooth bromegrass, level native, and the hilly native pastures (Table 2). When grazing was completed, the ungrazed residue (Table 2) remaining on the pastures also differed since all were grazed at similar stocking rates. The highest amount remained on the western wheatgrass pastures with the next highest amount on the crested wheatgrass pastures. Smooth bromegrass and level native pastures had similar quantities of residue remaining. Hilly native had the least.

More $(P<0.05)$ standing crop disappeared from western wheatgrass pastures than from the native pastures, but there was no difference among the other pastures, which suggested that quantity was not limiting (Table 2). Stubble measurements determined that little standing crop was grazed below the $5.0 \mathrm{~cm}$ mower height.

Utilization of the pastures averaged $35 \%$, which was light considering that the pastures were stocked $25 \%$ higher than the 1973 SCS recommended rate and grazed during drought conditions. Visually, western wheatgrass and crested wheatgrass pastures appeared to be underused; the others were more heavily used. Hart et al. (1988) reported a profitable stocking rate at approximately 60 to $80 \%$ above SCS recommended rates after several years of study. However, they questioned whether range condition could be main-

Table 2. Caged standing crop, ungrazed residue, crop disappearance, percent utilization, and steer gains after grazing seeded and native pastures for 133 continuous days (3-year average).

\begin{tabular}{|c|c|c|c|c|c|c|}
\hline Pasture & $\begin{array}{l}\text { Caged } \\
\text { crop }\end{array}$ & $\begin{array}{l}\text { Ungrazed } \\
\text { residue }\end{array}$ & $\begin{array}{c}\text { Crop } \\
\text { disappearance }\end{array}$ & Utilization & \multicolumn{2}{|c|}{ Steer gains } \\
\hline Level native & $\begin{array}{r}1810 \mathrm{~d} \\
\end{array}$ & $\begin{array}{c}-\left(\mathrm{kg} \mathrm{ha}^{-2}\right)- \\
1190 \mathrm{c}\end{array}$ & $630 \mathrm{~b}$ & $\begin{array}{l}(\%) \\
35\end{array}$ & $\begin{array}{c}\left(\mathrm{kg} \mathrm{head}^{-1}\right) \\
124 \mathrm{a}\end{array}$ & $\begin{array}{c}\left(\mathrm{kg} \mathrm{ha}^{-1}\right) \\
65 \mathrm{a}\end{array}$ \\
\hline Smooth bromegrass & $2140 \mathrm{c}$ & $1290 \mathrm{c}$ & $840 \mathrm{ab}$ & 39 & $114 b$ & $60 \mathrm{~b}$ \\
\hline Western wheatgrass & $3520 \mathrm{a}$ & $2470 a$ & $1040 \mathrm{a}$ & 30 & $108 \mathrm{bc}$ & $57 \mathrm{bc}$ \\
\hline Hilly native & $1500 \mathrm{e}$ & $860 d$ & $630 \mathrm{~b}$ & 42 & $106 \mathrm{c}$ & $56 \mathrm{c}$ \\
\hline Crested wheatgrass & $2830 \mathrm{~b}$ & $1970 \mathrm{~b}$ & $860 \mathrm{ab}$ & 30 & $105 c$ & $55 \mathrm{c}$ \\
\hline
\end{tabular}

IWithin columns, means followed by the same letter are not different at $P<0.05$ (Waller-Duncan test, $\mathrm{K}=100$ ). 
tained at those higher rates. We have included a heavy stocking intensity treatment in a subsequent study to determine stocking effects on the vegetation of the pastures and whether the western wheatgrass, crested wheatgrass, or other pastures can be utilized more intensively without sacrificing animal performance.

Of the 3 seeded species, smooth bromegrass is the least drought tolerant. This was visibly evident from the brown-colored, dormant appearance of the smooth bromegrass plants during much of the study, especially during late summer 1989. Smooth bromegrass stands in some areas of the pastures looked so poor in fall 1989 that we feared they would be partially lost, but they recovered in 1990 . In contrast, western wheatgrass pastures maintained a green color throughout the grazing season.

Caged standing crop and ungrazed residue were highest in 1988 when there was carryover from 1987 (Table 3). Drought began

Table 3. Caged standing crop, ungrazed residue, crop disappearance, and liveweight steer gain for 1988, 1989, and 1990 after graxing for 133 continuous days (average of 5 species).

\begin{tabular}{|c|c|c|c|c|}
\hline Year & $\begin{array}{l}\text { Caged } \\
\text { crop }\end{array}$ & $\begin{array}{l}\text { Ungrazed } \\
\text { residue }\end{array}$ & $\begin{array}{c}\text { Crop } \\
\text { disappearance }\end{array}$ & $\begin{array}{l}\text { Steer } \\
\text { gain }\end{array}$ \\
\hline 1988 & $2880 a$ & $\begin{array}{c}-\left(\mathrm{kg} \mathrm{ha}^{-2}\right) \\
1970 \mathrm{a}\end{array}$ & $910 \mathrm{a}$ & $\begin{array}{c}(\mathrm{ADG}, \mathrm{kg}) \\
0.76 \mathrm{~b}\end{array}$ \\
\hline 1989 & $2180 \mathrm{~b}$ & $1310 \mathrm{~b}$ & $870 a$ & $0.88 \mathrm{a}$ \\
\hline 1990 & $2020 \mathrm{~b}$ & $1390 \mathrm{~b}$ & $620 \mathrm{~b}$ & $0.87 a$ \\
\hline
\end{tabular}

Within columns, means followed by the same letter are not different at $P<0.05$ (Waller-Duncan, test, $K=100$ ).

reducing crop production and residue in 1988. Less crop disappearance was recorded in 1990 than in 1988 and 1989.

Averaged over all pastures, steer liveweight gain did not follow caged standing crop or crop disappearance (Table 3). Steer gain was higher in 1989 and 1990 when crop dry matter was lower. Crop disappearance includes vegetation eaten, trampled, and all other losses. Variability in vegetation measurements, differences in forage quality, and dissimilar opportunities for diet selection among the pastures all contribute to lack of correlation between forage disappearance and gain.

Stocking and pasture size differences were removed from our study by grazing identical sized pastures with 3 similar sized animals for the same period of time; therefore, statistical differences among the species pastured remained the same for gain per head and gain per pasture. Steers grazing the level native pastures gained the most weight over the 3 years (Table 2). Gains of steers grazing smooth bromegrass and western wheatgrass pastures were similar as were gains from western wheatgrass, hilly native, and crested wheatgrass. Year by pasture interactions were not significant. Pasture liveweight steer gain ha ${ }^{-1}$ was highest from the level native pastures (Table 2).

Cumulative liveweight steer gain over the season was similar for all pastures from the start of grazing through mid-August (Fig. 1). Mid-May is about the earliest the native pastures are ready for grazing in North Dakota which determined our starting date. Cool-season species, especially crested wheatgrass, usually provide a green standing crop that is ready for grazing by late April to early May. Pastures composed of these species can be used to advantage by grazing them first and then grazing native range. Starting grazing about mid-May did not give seeded pastures a liveweight gain advantage over the native pastures during the early part of the grazing season. At mid-August average liveweight gains remained no different $(P<0.05)$ among pastures and averaged $84 \mathrm{~kg} \mathrm{head}^{-1}$. Early September gain from level native pasture was higher $(P<0.05)$ at $105 \mathrm{~kg} \mathrm{head}^{-1}$ than from the other pastures which averaged $91 \mathrm{~kg}^{\text {head }}{ }^{-1}$. Accumulated gain from level native pas-

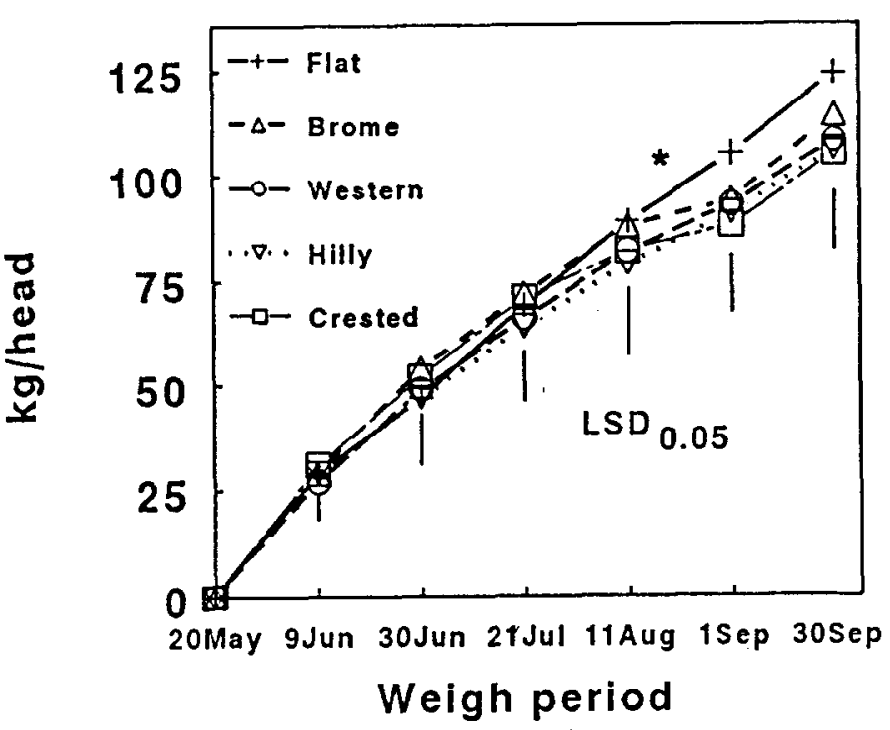

Fig. 1. Cumulative liveweight gain of steers grazing seeded and native pasture at periodic dates throughout a 133-day season (3-year average.) * Gains between periods are different $(P<0.05)$ except for smooth bromegrass between 11 Aug. and 1 Sept.

tures exceeded gain from the other pastures at the end of September. Still, the 0.79 to $0.86 \mathrm{~kg}^{-1} \mathrm{hd}^{-1}$ ADG obtained from the seeded and hilly native pastures compared favorably with the 0.82 $\mathrm{kg}$ head $^{-1}$ ADG reported by Sarvis (1941) for native range grazed for 137 days at the rate of 1 steer to 2.8 ha.

\section{Conclusion}

Continuous, season-long grazing is the most common method of grazing native range in the northern Great Plains. Cattle are put on pastures relatively early in spring, late April to mid-May, and left to graze through fall or until the standing crop is gone. This results in a simple management, low input, sustainable use of the native grass crop.

Presently, a similar season-long grazing treatment is not recommended for pastures that have been seeded to species such as crested wheatgrass or smooth bromegrass because of poor mid- to late-summer animal performance on these pastures compared with native pastures. Most grazing recommendations for seeded pastures follow Williams and Post's (1945) suggestion to stock heavily enough to prevent the cool-season species from becoming coarse and mature. Thus, stocking intensity on cool-season grass pastures is higher than for native range, which increases standing crop utilization.

This study compares grazing cool-season and native pastures seasonlong. Hart et al. (1988) cautioned that stocking rate must be the same when comparing grazing systems. We applied the same caution for comparing grazing of species; therefore, our study differs from most older studies. Our results suggest that seeded introduced species produced acceptable liveweight steer gain when grazed at the stocking rate recommended for native range. Our pasture gains were similar to the maximum gain of $59.5 \mathrm{~kg} \mathrm{ha}^{-1}$ on range producing $1,170 \mathrm{~kg} \mathrm{DM} \mathrm{ha}^{-1}$ and grazed 150 days at 105.5 steer days ha $^{-1}$ in Wyoming calculated by Hart et al. (1988). No special effort or additional inputs were used to achieve these gains during the 3 years. The seeded pastures consisted of relatively pure stands of seeded species and results may change if species are seeded in mixtures because of palatability differences.

Seed of these cool-season grass species is readily available, inexpensive, and stands are easy to establish. They appear to be a viable alternative to native seeding mix for converting marginal or other 
cropland into grass for grazing. Likewise, CRP lands that have been seeded to cool-season introduced grasses may provide seasonlong grazing from highly erodible soils on a sustained basis.

\section{Literature Cited}

Frischknecht, N.C., and L.E. Harris. 1968. Grazing intensities and systems on crested wheatgrass in central Utah: response of vegetation and cattle. USDA Tech. Bull. 1388.

Hart, R.H., M.J. Samuel, P.S. Test, and M.A. Smith. 1988. Cattle, vegetation, and economic responses to grazing systems and grazing pressure. $J$. Range Manage. 41:282-286.

Hofmann, L., and R.E. Ries. 1989. Animal performance and plant production from continuously grazed cool-season reclaimed and native pastures. J. Range Manage. 42:248-251.
Laycock, W.A., and T. Layden. 1985. Cattle production on reclaimed mined lands in northwestern Colorado. p. 162. In: P.J. Joss, P.W. Lynch, and O.B. Williams (eds.) Rangelands: A resource under siege. Proc. 2nd Int. Rangeland Congr., Australian Acad. Sci., Canberra.

Rogler, G.A., and R.J. Lorenz. 1969. Pasture productivity of crested wheatgrass as influenced by nitrogen fertilization and alfalfa. USDA Tech. Bull. 1402.

Rogler, G.A., R.J. Lorenz, and H.M. Schaaf. 1962. Progress with grass. North Dakota Agr. Exp. Sta. Bull. 439.

Sarvis, J.T. 1941. Grazing investigations on the Northern Great Plains. North Dakota Agr. Exp. Sta. Bull. 439.

Williams, R.M., and A.H. Post. 1945. Dry land pasture experiments. Montana Agr. Exp. Sta. Bull. 431. 